\title{
Local Government and Its Development Capabilities in Nigeria: A Study of Nassarawa Local Government
}

\author{
Mohammed Bello \\ Department of History, Faculty of Arts and Islamic Studies, Bayero University, Kano, Kano State, Nigeria
}

\begin{abstract}
The paper examined Local Government and its development capabilities in Nassarawa Local Government Area of Kano State. The theoretical framework for this paper is anchored on Amartya Sen's capability approach. The first clarification that needs to be made is to ask whether the capability approach is a well-defined theory, or something broader, like a paradigm. In its most broad form, the capability approach can indeed be considered to be a paradigm. However, not everyone uses it as such. It could help to distinguish between three different levels at which the capability approach is operating: first, as a framework of thought for the evaluation of individual advantage and social arrangements. Second, as a critique of other approaches to the evaluation of well-being and justice. Third, as a formula or algorithm to make interpersonal comparisons of welfare or well-being. The capability approach is primarily and mainly a framework of thought, a mode of thinking about normative issues, hence - loosely defined - a paradigm. Sen has stressed that the capability approach can be used for a wide range of purposes (Sen, 1993). What does it mean to see the capability approach as a general framework of thought for the assessment of individual advantage and social arrangements? The capability approach focuses on the information that we need to make judgments about individual well-being, social policies, and so forth, and consequently rejects alternative approaches that it considers normatively inadequate, for example when an evaluation is done exclusively in monetary terms. The paper utilized primary data collected from a sample of 267 respondents using self-administered questionnaire, descriptive statistical technique using simple percentage presented in form of table and chart was employed to analyze the data collected. The paper revealed that Nassarawa Local Government has the capability to act and commit, that Nassarawa Local Government deliver on development projects; that Nassarawa Local Government has the capability to relate with external stakeholders, and that Nassarawa Local Government adapt and self-renew. The paper, therefore recommends; that the Nassarawa Local Government should improve on her capability to act and commit by ensuring that it effectively able to make decisions and commitments on viable policies that will improve the development capabilities of the Local Government, that the Nassarawa Local Government should improve on her capability to deliver on development projects by ensuring that the local government have sufficient and capable staff; clear organizational responsibilities; adequate financial resources; and effective administrative mechanisms in place, that the Nassarawa Local Government should improve on its capability to adapt and self-renew by regularly monitoring and evaluating the progress made on its development objectives, and encourage internal learning and reflection, that the Nassarawa Local Government should improve on her capability to relate with external stakeholders by adopting the policy of
\end{abstract}

Public-Private Partnership as well as establishing a cordial relationship with NGs and international organizations.

Key Words: Local Government; Development, Capabilities, Approach, Act, Commit.

\section{INTRODUCTION}

$\mathrm{L}$ ocal governments are essential actors in both the challenges and opportunities of urbanization, with their own specific and complementary role in creating an enabling environment at the local level for economic and social development. At their own level, they can promote, facilitate, and regulate the local economic and social activity, deliver local public goods, and enforce local laws and regulations. As such, urban growth helps drive the increasing imperative for effective local government (Hans and Jamie, 2015).In practice, local governments are often keen to assume their responsibilities but face a series of constraints, including staff shortages, inadequate budgets, and weak institutional capacity. These constraints in turn typically result in several problems: low performance in service delivery, unmotivated staff, and dissatisfaction of the general public (Hans and Jamie, 2015). Perhaps the most difficult constraint to resolve is that of local government capacity: capacity development is needed not only for local governments to fulfill their functional responsibilities, but institutional capacity is also required to be able to generate more income and to hire more staff (Hans and Jamie, 2015).

Local governments in Nigeria are single-tier government responsible for providing basic services to the people. Local governments exist to provide peculiar services, particularly to rural communities. Countries all over the world, irrespective of the system of government, sees local government as an essential instrument of national or state government for the performance of certain basic services which could best be administered locally as the intimate knowledge of the needs, conditions, and peculiarities of the areas concerned rest with the tier. It also unites people in a defined area in a common organization whose functions are essentially complementary to those of the central government and in the interest of the local residents for the satisfaction of common community needs. As a government, it is the means by which the common problems and needs of a community are economically and effectively catered for. This shows that local government is the major source by which a local community satisfies their common needs and problems. 
However, the performance of Local Governments in Nigeria was characterized by some challenges which includes; funding, autonomy, infrastructural decay, political instability, constitutional problems, etc. Unfortunately, in Nigeria over the years, local governments have largely failed in their responsibilities. Despite attempts to bring government closer to the people by increasing the number of local governments in the country, the quest for the development of local governments has still not been met (Otoghile and Edigin, 2011). Despite the various Local Government reforms in Nigeria and the recognition of its role, this level of government has remained in the rot and has not been able to achieve its aim of grassroots democracy and sustainable development in Nigeria (Oni and Joshua, 2014).Against this background, the paper intends to examine the development capability of Nassarawa Local Government Area of Kano State. The remaining sections of this paper includes; the literature review and theoretical framework, methodology, analysis and discussion of the result, as well as conclusion and recommendations.

\section{LITERATURE REVIEW AND THEORETICAL FRAMEWORK}

\subsection{Literature Review}

The concept of development over the years has been conceived as a process of economic and social changes with the aim of achieving a better life. Only a few analysts have stopped to ask themselves if these changes could be for the worse for some sectors of society and better for others. It is very useful to retain the positive value placed on the term development and see development as first of all the escape of man out of the conditions of exploitation, poverty and oppression (Otoghile and Edigin, 2011) and that development involves changes in the basic institution and structures of society. Walter Rodney sees development in human society as a many-sided process. To him, at the level of an individual, it implies increased skill and capacity, greater freedom, creativity, self-discipline, responsibility and material wellbeing. He further argued that some of these indicators are completely moral categories and are very difficult to evaluate. For him, at the level of social groups, it implies an increasing capacity to regulate both internal and external relationships (Rodney, 1972:9). Schumpeter disagreed with the mere use of economic indicators as recorded growth of output and income to indicate economic growth. For him, the economic growth indicated by such factors or indicators is mere changes in data (Otoghile and Edigin, 2011). According to Todaro (1981:56), development is a multi-dimensional process involving the reorganization and re-orientation of the entire economic and social system. In addition to improvement in income and output, it typically involves radical changes in institutional, social and administrative structures as well as in a particular attitude and in many cases even customs and beliefs. In Seer's view, the questions to ask about a country's development are: What has been happening to unemployment? What has been happening to inequality? What has been happening to poverty? If all these have declined from high levels, then no doubt this has been a period of development for the country concerned. If one or two of these central problems have been growing worse especially if all three have, it would be strange to call the result development; even if per-capita income doubted (Otoghile and Edigin, 2011).

On the other hand, capability involve organized activity and the exercise of capability is typically repetitious in substantial part (Benjamin, 2002). However, capability is not just capacity, even though capacity has a bearing on it. Capability emerges from a combination of Skill and Knowledge (technical or functional ability), Capacity (emotional ability to cope), and Intent (ability to commit - the will to do). This is another take on being 'ready, willing and able'. If any of these three is weak or absent, there will be a lack of capability and the battle may be lost. Capability is thus a set of vectors of functioning, reflecting the person's freedom to lead one type of life or another" (Sen, 1992: Ingrid, 2003). Capabilities, in contrast, "are notions of freedom, in the positive sense: what real opportunities you have regarding the life you may lead" (Sen 1987: Ingrid, 2003).

Meanwhile, Ola (1984) defined local government as a political sub-division of a nation, which is constituted by law and has substantial control of local affairs including the powers to impose taxes or to exact labor for a prescribed purpose. According to Blair (1977), Local Government is rather a resident population occupying a defined area that has a locally authorized and governing body; a separate legal entity, the power to provide certain public or governmental services, and a substantial degree of autonomy adding legal or actual power to raise part of its revenue. The Guidelines for 1976 Local Government reform, defined local government as government at the local level established by law to exercise specific powers within defined areas and to initiate and direct the provision of services and to determine and implement project so as to complement the activities of the state and federal government in their areas, and to ensure that local initiative and response to local needs and conditions are maximized (Doho, Ahmed, \& Umar 2018). In the view of a scholar like Wraith, local government refers to locally elected councils whose main purposes are to provide or administer services with a great degree of independence as modern circumstances allow (Wraith, 1964:15-16). For Golding, local government is the management of their own affairs by the people of their locality (Otoghile and Edigin, 2011). Asaju (2010) distinguished Local Government depending on the political arrangement of the nation, i.e. unitary or federal system. Adeyeye (2000) defines Local Government in the unitary state as a "non-sovereign community possessing the legal right but which are essentially administrative agents of the central government". On the other hand, the United Nations Office for Public Administration sees Local Government as; a political sub-division of a nation-state, which is constituted by law and has substantial control of local affairs including the powers to impose taxes or to exact 
labour for prescribed purposes and the governing body of such an entity is elected.

Similarly, the Guideline for Local Government Reform (FGN, 1976: Asaju, 2010) defines Local Government as; Government at the local level exercised through representative councils established by law to exercise specific powers in defined areas. These powers should give the council substantial control over local affairs as well as the staff and institutional and financial power to initiate and direct the provision of service and to determine and implement projects so as to complement the activities of the state and federal government in their areas, and to ensure, through devolution of functions to these councils and through the active participation of the people and their traditional institutes, that local initiative and responses to local head and conditions are maximised.

Umar and Abdu (2018) assessed housing quality and sustainable development in Nassarawa Local Government, Kano State and reports. The study revealed that majority of the respondents live in traditional houses; that, majority of the houses are occupied by only one household, and source their water from wells and water vendors. The study further revealed that most of the houses in the study area have only one window and are small with little ventilation, that majority of the residents dispose waste in unauthorized dumping sites. In addition, the study revealed that more than half of respondents live in dirty and noisy housing environment, that majority of houses in the study area have no landscaping and lack adequate public facilities. The finding also revealed that the direction window faces makes the strongest unique contributions in explaining the variation of ventilation and room lighting. Aiguosatile and Lambert (2011) examined Local Government administration and development in Oredo Local Government Area of Edo State. The study revealed that though funds available to Local Governments are grossly inadequate, there is the general impression that the little funds made available are directed into private pockets. Dang (2013) examined the impact of revenue allocation on economic development in Nigeria and reports that revenue allocations have significant causal relationship with economic development in Nigeria, with only revenue allocation to states having significant negative relationship. furthermore, unidirectional causality runs from revenue allocations to real GDP in Nigeria.

Similarly, Salahudeen (2018) examined the accessibility and distribution of domestic water supply in Nassarawa Local Government Area of Kano State, Nigeria. The study revealed that majority of the vended water is sourced from outside Nassarawa Local Government and mostly from shallow wells/stand pumps located at the extreme North Western part of the study area. The study also, revealed that majority of the residents in the study area patronise the services of water vendor, with majority buying their water from pushcarts water vendors, while some buy theirs from tanker truck vendors and head carriage vendors. The study further revealed that most households are not connected to pipe borne water network connection, and that among those connected, majority receives duration of water flow from the tap between 1.5 to 6 hours. Kaka (2018) examined decentralization of Local Government and Rural Development in Rivers State, Nigeria. He reports that Community Development Committees (CDCs) protected personal and political interests of the elites, excluded the voice of the local citizens, lacked representation from the minority, and CDC officials mismanaged funds and resources.

Furthermore, Oduro-Ofori (2011) investigated the role of Local Government on Local Economic Development (LED), in Ghana by utilizing both primary and secondary data. Major findings of the study revealed that though the local government played several roles in LED, these were mainly traditional and not directly effective to rapidly address the LED needs of the municipality. The various strategies and tools applied were also limited in scope. The local government was also less committed to the implementation of programmes and projects stated in its development plans that were of direct benefit to economic entities in municipality. More so, it had inadequate capacity in terms of funds, logistics and human resources. In addition, it depended to a larger extent on the central government for most of its capacity needs. It also had a weak institutional set-up for LED promotion which affected negatively the coordination of LED initiatives. The LED process was also not well integrated into the local government's development planning process. Moreover, the local government's involvement of other stakeholders in its LED process was limited to informing and consulting. It maintained a weak relationship with local stakeholders and a higher one with external stakeholders. There was also the absence of a clear platform for stakeholder engagement by the local government in its LED process. Other external factors influencing its performance in the LED process included the absence of a national policy framework to guide its involvement in LED, hindered access to the utilisation and control of certain local resources and the inadequate capacity of local economic entities in the municipality.

Similarly, Manyi (2007) examines the role of Local Governments on rural development in Buea, Cameroon using primary data. Major findings of the study revealed that power has not been devolved in its entirety from the central government to the decentralized units and that the rural masses are still not empowered and therefore do not participate fully in the development of Buea. The result further revealed that in Cameroon, there is decentralization without empowerment. The state has officially espoused democratic ideals but its practicality is absent. Analysis of the data on elections suggests that the Buea Rural Council is not representative of the Buea folk because the council representatives are not the choice of the people. Johnsen (1999) explored the limits of certain theories on the economics of organisation in explaining public sector 
management in Norway. The study revealed that contrary to conventional wisdom, performance measurement was found to be extensively used and particularly under asymmetric information and uncertainty.

\subsection{Theoretical Framework}

The theoretical framework for this paper is anchored on Amartya Sen's capability approach. The first clarification that needs to be made is to ask whether the capability approach is a well-defined theory, or something broader, like a paradigm. In its most broad form, the capability approach can indeed be considered to be a paradigm. However, not everyone uses it as such. It could help to distinguish between three different levels at which the capability approach is operating: first, as a framework of thought for the evaluation of individual advantage and social arrangements. Second, as a critique of other approaches to the evaluation of well-being and justice. Third, as a formula or algorithm to make interpersonal comparisons of welfare or well-being.

The capability approach is primarily and mainly a framework of thought, a mode of thinking about normative issues, hence - loosely defined - a paradigm. Sen has stressed that the capability approach can be used for a wide range of purposes (Sen, 1993). What does it mean to see the capability approach as a general framework of thought for the assessment of individual advantage and social arrangements? The capability approach focuses on the information that we need to make judgments about individual well-being, social policies, and so forth, and consequently rejects alternative approaches that it considers normatively inadequate, for example when an evaluation is done exclusively in monetary terms. The capability approach also identifies social constraints that influence and restrict both well-being as well as the evaluative exercises. The capability approach can be used to measure poverty or inequality or can be used as an alternative for traditional utilitarian cost-benefit analysis. It is a perspective that can be applied to efficiency evaluations. It can serve as an important constituent for a theory of justice but, as Sen argues, the capability approach specifies an evaluative space and this does not amount to a theory of justice (Sen, 1995). He stresses that a theory of justice must include both aggregative considerations as well as distributive ones, whereas the capability approach does not specify an aggregative principle. An important illustration of how the capability approach can be used as such a broad framework of analysis and evaluation is Sen's own work with Jean Drèze on development in India (Drèze and Sen, 2002).

At the second place of importance is the capability approach as a critique, mainly on the welfarist approaches in welfare economics and on utilitarian and income- or resources based theories. Sen rejects welfarist theories because, whatever their further specifications, they rely exclusively on utility and thus exclude non-utility information from our moral judgments(Sen, 1979). Thus, Sen is concerned not only with the information that is included in a normative evaluation, but he is as much concerned with the information that is excluded. The non-utility-information that is excluded by utilitarianism could be a person's physical needs due to handicaps, but also social or moral aspects, such as the principle that men and women should be paid the same wage for the same work. For a utilitarian, this principle has no intrinsic value, and men and women should not be paid the same wage as long as women are satisfied with lower wages. But it is counter-intuitive, Sen argues, that such principles would not be taken into account in our moral judgments. Thus, the first strand of normative theories that Sen attacks are those that rely exclusively on mental states. This does not mean that Sen thinks that mental states, such as happiness, are unimportant and have no role to play; rather, it is the exclusive reliance on mental states which he criticizes.

The capability approach entails also a critique (albeit often in very diplomatic wording) of how economists have applied the utilitarian framework for empirical analysis in welfare economics. Economists use the utility as the focal variable in theoretical work, but translate this into a focus on income in their applied work. Sen has argued that, while income can be an important means to advantage, it can only serve as a rough proxy for what intrinsically matters, namely people's capabilities. He argues that "the informational bases of justice cannot be provided by comparisons of means to freedom (such as "primary goods", "resources" or "incomes")" (Sen 1990b). While Sen has often acknowledged his debt to the philosopher John Rawls, he also criticises Rawls's concentration on primary goods, because it neglects the importance of the diversity of human beings. If all persons were the same, then an index of primary goods would tend to yield similar freedoms for all; but given human diversity, the Rawlsian justice conception will fail to take note that different people need different amounts and different kinds of goods to reach the same levels of well-being or advantage. In a similar vein, Sen has criticised other resources-based normative theories, such as Ronald Dworkin's account of equality of resources (Sen 1984). More recently, Martha Nussbaum has significantly extended the capability critique on Rawls by not only focusing on the difference between primary goods and capabilities but also examining the implications of the fact that Rawls's theory of justice belongs to the social contract tradition, whereas the capability approach does not (Nussbaum, 2002a). However, Pogge (2002) recently has argued against the capability approach to justice, and in favour of a Rawlsian approach; it is clear that the debate on the pros and cons of Rawlsian justice versus capability justice is far from closed.

On a third and least important level is the capability approach as a formula for interpersonal comparisons of welfare. The focus here is on a formula, in the sense that the capability approach would provide a neat recipe or even an algorithm to carry out empirical exercises in welfare comparisons. Some economists have tried to read Sen's writings on the capability approach looking for such a formula or algorithm (Roemer, 
1996), and have consequently been disappointed when they discovered that this has not been Sen's primary focus.

The capability approach was conceived in the 1980s as an alternative approach to welfare economics. In this approach, Amartya Sen and Martha Nussbaum bring together a range of ideas that were previously excluded from (or inadequately formulated in) traditional approaches to the economics of welfare.

\section{METHODOLOGY}

\subsection{Overview of the Study}

Nassarawa is a Local Government Area in Kano State with an area of $34 \mathrm{~km}^{2}$ and a population of 678,669 (National Population Commission, 2006). Nassarawa is one of the fortyfour local government areas of Kano state and is located in the central part of Kano state senatorial zone with its capital administrative headquarters in the Bompai. Among other wards of the Nassarawa Local Government includes; TudunMurtala, Kawaji, Gama, Dakata, Giginyu, Gwagwarwa, Hotoro north, Hotoro south, and Kaura-Goje. The map below depicts the location of the local government with the 11 wards and their boundaries.

Figure 3.1: Map of Nassarawa Local Government Area

\section{STATE: KANO}

LGA: NASSARAWA

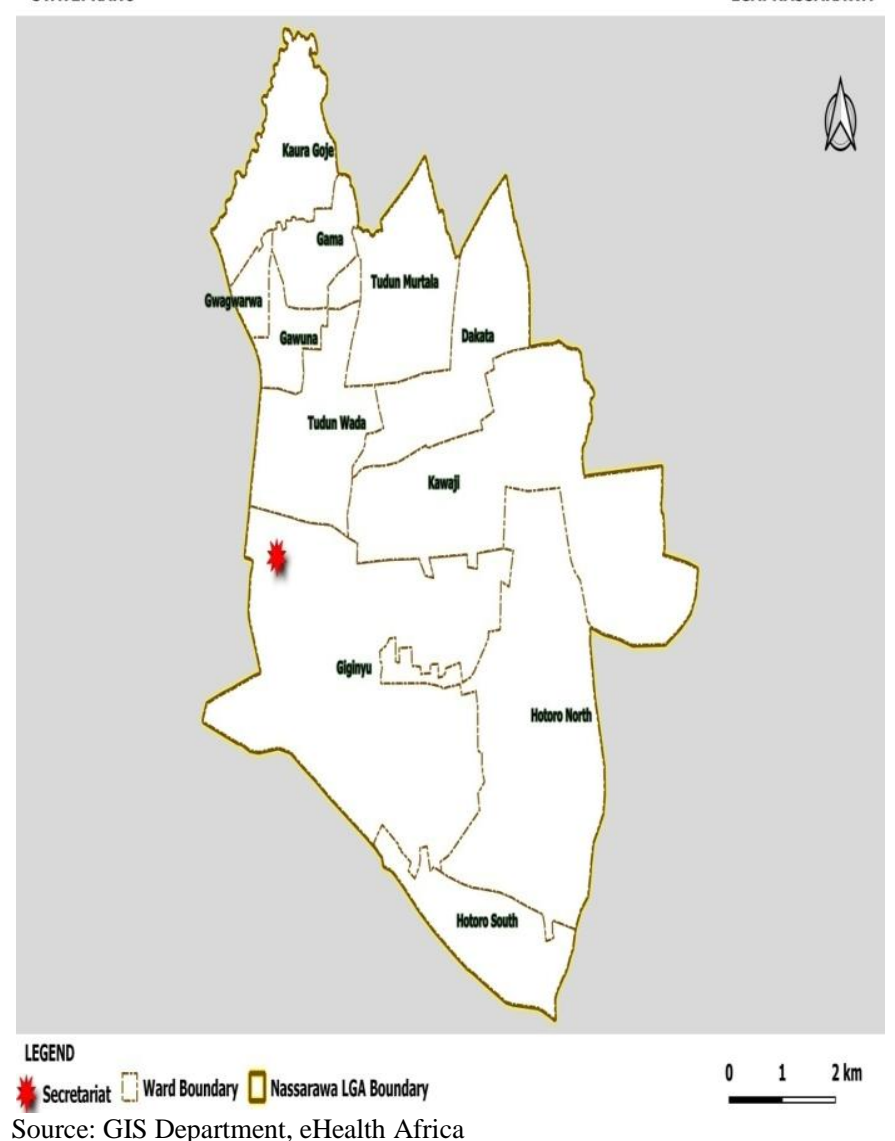

The Nassarawa Local Government Councils heads the public administrations in Nassarawa local government area which is made up of eleven wards represented by eleven councilors inclusive of the chairman who heads the executive arm of the local government while super-seeing the social and economic development and projects in the area and thus serving as an intermediary between the state government and the people.

\subsection{Research Design}

According to Andrew (2018), research design is the set of methods and procedures used in collecting and analyzing measures of the variables specified in the research problem. A research design is a framework that has been created to find answers to research questions. A research design will typically include how data is to be collected, what instruments will be employed, how the instruments will be used and the intended means for analyzing data collected.

Therefore, the population of the study for this paper consists of the entire staff of Nassarawa Local Government totaled 806 from various departments which includes; works and housing, personnel, community, wash, primary healthcare, agriculture, treasury, and planning, research and statistics as shown in table 3.1 .

Table 3.1: Population of the Study

\begin{tabular}{|c|c|}
\hline Works and Housing & 37 \\
\hline Personnel & 187 \\
\hline Community & 65 \\
\hline Wash & 15 \\
\hline Primary Healthcare & 370 \\
\hline Agriculture & 22 \\
\hline Treasury & 107 \\
\hline Planning, Research \& Statistics & 3 \\
\hline Total & $\mathbf{8 0 6}$ \\
\hline
\end{tabular}

Source: Nassarawa Local Government Staff Register

To determine appropriate sample size that will represent the entire population, the paper employed Yamani's formula as specified in equation 3.1 :

$$
\mathrm{n}=\frac{N}{1+\mathrm{Ne}^{2}}
$$

Where $\mathrm{n}$ represents sample size, $\mathrm{N}$ represents total population, e represents level of significance

Substituting $\mathrm{N}=806$, and $5=0.05(5 \%)$ in equation 3.1

$$
\mathrm{n}=\frac{806}{1+806(0.05)^{2}}=267.33 \approx 267
$$

Therefore, the appropriate sample size for the paper is approximately 267. The study further employed simple proportion method to determine the portion of the sample for each department or unit as shown in table 3.2. 


\begin{tabular}{|c|c|}
\hline Works and Housing & 12 \\
\hline Personnel & 62 \\
\hline Community & 22 \\
\hline Wash & 5 \\
\hline Primary Healthcare & 123 \\
\hline Agriculture & 7 \\
\hline Treasury & 35 \\
\hline Planning, Research \& Statistics & 1 \\
\hline Total & $\mathbf{2 6 7}$ \\
\hline
\end{tabular}

Source: Author's Computation

Furthermore, the study will use purposive sampling techniques to access the respondents. This is a type of sampling techniques in which the researcher chooses the respondents based on his own personal judgment, keeping in mind the purpose of the study. Purposive sampling techniques will be used because it is less costly, more readily accessible, more convenient and select only those individual that are relevant to research design.

In order to collect the data from the respondents, the paper employed questionnaire technique of data collection. The questionnaire was filled by the respondents and includes both closed and open ended questions. The questionnaire was divided into two sections; section A contains the demographic information of the respondents, while section B contains questions related to development capability of Nassarawa Local Government.

\subsubsection{Descriptive Statistical Technique}

To analyze the data collected, the study employed descriptive statistics using a simple percentage. This method of data analysis was used due to its simplicity. The formula for a simple percentage can be specified as:

S.P. $=\frac{X}{N} \mathrm{X} 100$

Where S.P. = simple percentage,

$\mathrm{X}=$ required number, and $\mathrm{n}=$ total number of observation

Additionally, the paper used other descriptive statistics such as; pie chart and bar chart to analyze the result.

\section{ANALYSIS AND DISCUSSION OF THE OF THE RESULT}

\subsection{Response Rate of the Respondents}

In this section, the study discussed the response rate of questionnaire administered. A total of 267 questionnaires were administered and the entire questionnaires were returned valid. The response rate of the questionnaire presented in table 4.1 shows that response rate is $100 \%$ successful.

\begin{tabular}{|c|c|c|}
\hline Response & $\begin{array}{c}\text { Number of } \\
\text { Questionnaire }\end{array}$ & Percentage \\
\hline Return & 267 & 100.0 \\
\hline Not Return & 0 & 0 \\
\hline Total & 267 & 100.0 \\
\hline
\end{tabular}

Source: Author's Computation

\subsection{Demographic Information of Respondents}

Understanding the nature and composing of a particular population is of paramount importance. In this regard, the paper analyzed the demographic characteristics of the staff of Nassarawa Local Government with respect to gender, marital status, age, and qualification of respondents.

The result of the gender distribution of the respondents presented in figure 4.1 shows that out of the 267 respondents, 199 representing $74.5 \%$ were males while 68 representing $25.5 \%$ were females. This implies that more than $70 \%$ percent of the staff of Nassarawa Local Government are males with a very low proportion of female, indicating high rate of gender inequality in the recruitment process in the Local Government.

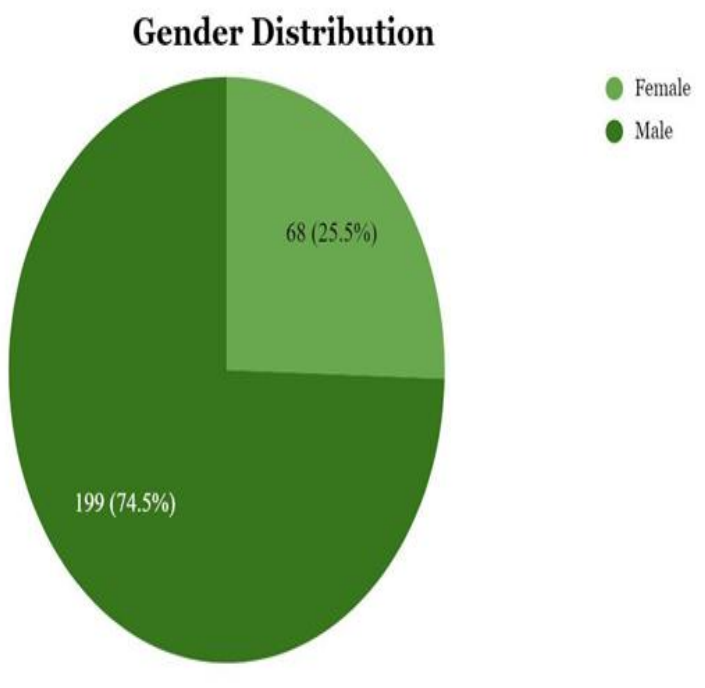

In terms of the marital status of the staff of Nassarawa Local Government, the result presented in figure 4.2 shows that out of 267 staff of Nassarawa Local Government, about 209 representing $78.3 \%$ were married while about 44 representing $16.5 \%$ were single. The remaining were widow and divorcees. This result implies that there is wide disparity between married and single among the staff of Nassarawa Local Government with a few widows and divorcees. 


\section{Marital Status Distribution}

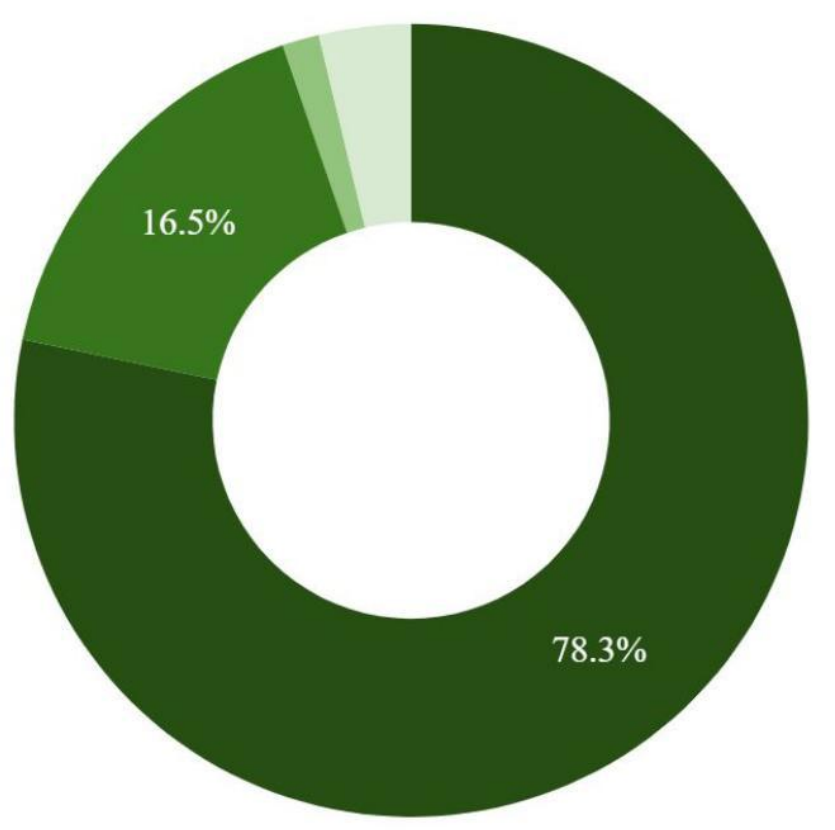

Married

Single

Widow

Divorced

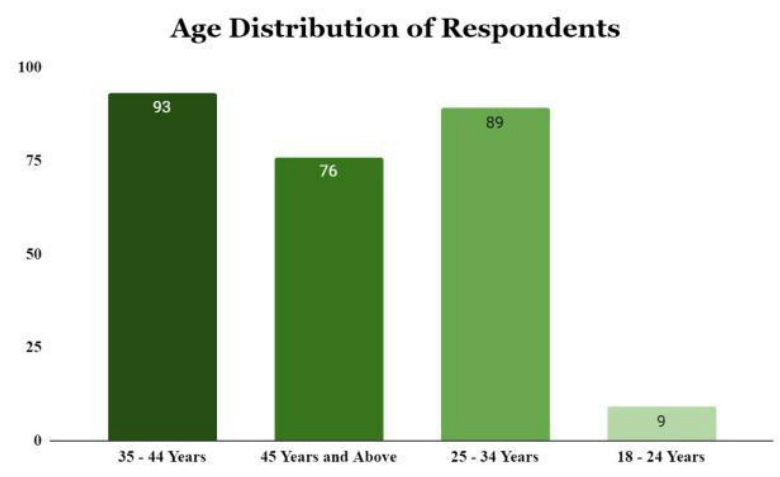

Figure 4.2:1

Similarly, result of age of respondents presented in figure 4.2:1 shows that out of 267 respondents, 93 representing $34.8 \%$ falls within the age group 35-44 years, followed by 89 representing $33.3 \%$ respondents. The age group 45 years and above has 76 respondents representing $28.5 \%$ while the age group 18-24 years were the lowest with only 9 representing $3.4 \%$ of respondents. This implies that more than $68 \%$ of the staff of Nassarawa Local Government aged 35 years and above while about $32 \%$ were less than 35 -year old. This indicates that the proportion of the youth among the staff of Nassarawa Local Government is very low.

With respect to the qualification of respondents, the result presented in figure 4.2:2 shows that out of 267 respondents, 110 representing $41 \%$ are graduate with B Sc, B Ed, and HND certificates; followed 91 respondents representing $34 \%$ with

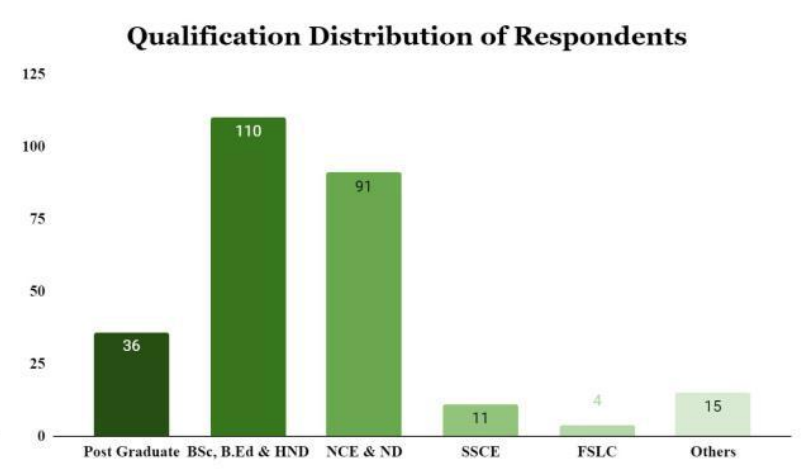

Figure 4.2:2

NCE/ND certificates. The result further indicated that those with postgraduate certificates were only 36 representing $13.5 \%$ while the remaining possessed SSCE, FSLC, and other qualification. This result implies that $88.5 \%$ of staff of Nassarawa Local Government attended tertiary institution while only few attended secondary school and below.

\subsection{Development Capability of Nassarawa Local Government}

In this section, the study examines the development capability of Nassarawa Local Government. These includes; the capability of Nassarawa Local Government to act and commit to development, the capability of Nassarawa Local Government to deliver on development projects, the capability of Nassarawa Local Government to adapt and self-renew its capacity building, the capability of Nassarawa Local Government to relate with external stakeholders, and the 
capability of Nassarawa Local Government to achieve coherence.

The result presented in figure 4.3.1 shows that about 236 of the respondents representing $88.4 \%$ agreed that the Nassarawa Local Government has the capability to act and commit to development. However, about 13 respondents representing $4.9 \%$ said that the Local Government do not have the capability to act and commit to development, while about 18 respondents representing $6.7 \%$ remain silence. Therefore, the paper concludes that the Nassarawa Local Government has the capability to act and commit to development.

Also, the respondents were asked whether the projects executed by the Nassarawa Local Government meet community needs. The result presented in figure 4.3:2 shows that out of 267 respondents, 229 representing $85.8 \%$ agreed that the projects meets community needs; while the remaining 38 respondents representing $14.2 \%$ said that the projects do not meet community needs. Therefore, the paper concludes that, the Nassarawa Local Government deliver on development projects.

Figure 4.3: Capability of Nassarawa Local Government to Act and Commit to Development and Deliver on Development Projects

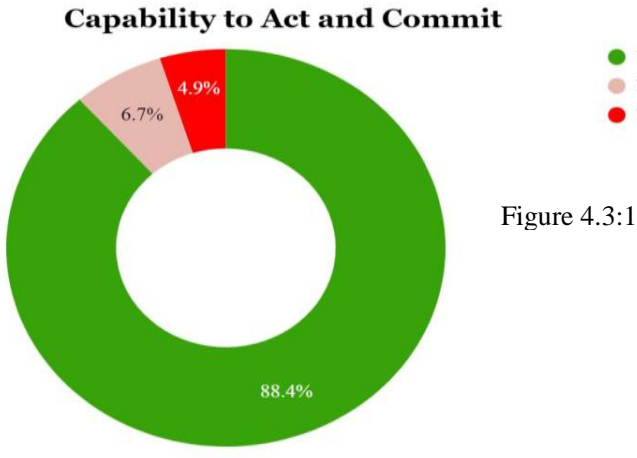

Do projects meet community needs?

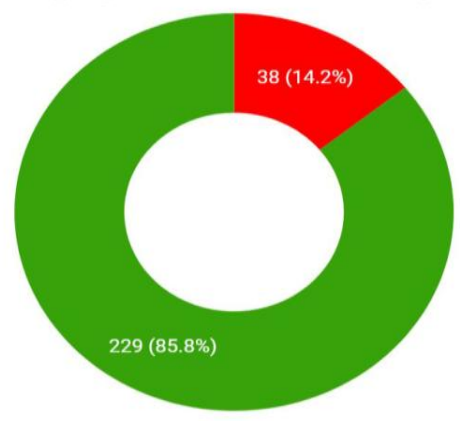

- No

Figure 4.3:2

In order to examine the capability of Nassarawa Local Government to relate with external stakeholders, the respondents were asked their view about the quality of service and the quality of goods and services from interventions to the Local Government. The result presented in figure 4.4.1 shows that out of 267 respondents, 143 representing 54\% viewed that the quality of services is moderate while 93 respondents representing $35 \%$ viewed that the quality of service is high and another 16 respondents representing 6\% maintained that the quality of service is very high. However, 13 respondents representing 5\% and another 2 representing $1 \%$ maintained that the quality of service are poor and very poor respectively.

Similarly, the result of figure 4.4:2 further shows that out of 267 respondents 128 representing $48 \%$ viewed that the quality of goods and services from interventions to the Local Government are very good while 97 respondents representing $36 \%$ viewed that the quality of goods and services from interventions to the Local Government are good and another 40 respondents representing $15 \%$ said that the quality of goods and services from interventions to the Local Government are excellent. However, only 2 respondents representing $1 \%$ said that the quality of goods and services from interventions to the Local Government are poor. Therefore, the paper concludes that the Nassarawa Local Government has the capability to relate with external stakeholders.

Figure 4.4: Capability of Nassarawa Local Government to Relate with External Stakeholders

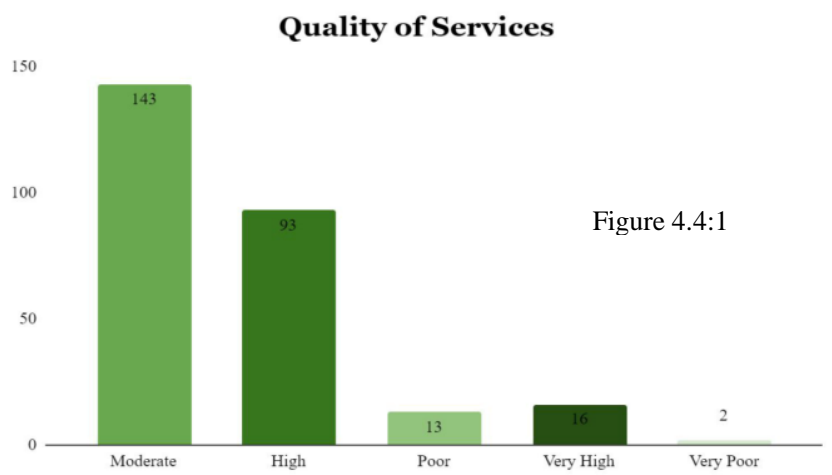

Quality of Goods and Services from Interventions to the LGA 150

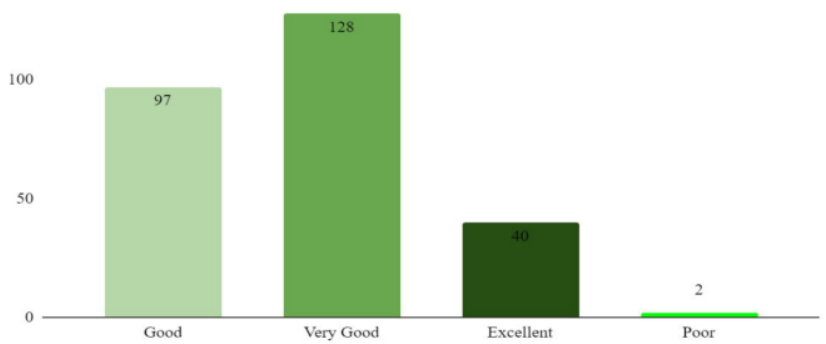

Figure 4.4:2

To examine the capability of Nassarawa Local Government to adapt and self-renew its capacity building, the respondents were asked their view about the effect of capacity building activities on staff's performance, satisfaction with fund 
utilization, and the provision of infrastructural development. The result presented in figure 4.5 shows that out of 267 respondents, 127 respondents representing $48 \%$ viewed that capacity building activities has a very good effect on staff's performance while 112 respondents representing $42 \%$ viewed that capacity building activities has a good effect on staff's performance and another 17 respondents representing 6\% viewed that the effect of capacity building activities on staff's performance is excellent. However, 10 respondents and another 1 representing $4 \%$ and $0.4 \%$ viewed that the effect of capacity building activities on staff's performance are poor and very poor respectively.

Figure 4.5: Effect of Capacity Building Activities on Staff's Performance

\section{Effect of Capacity Building Activities on Staff's Performance} 150

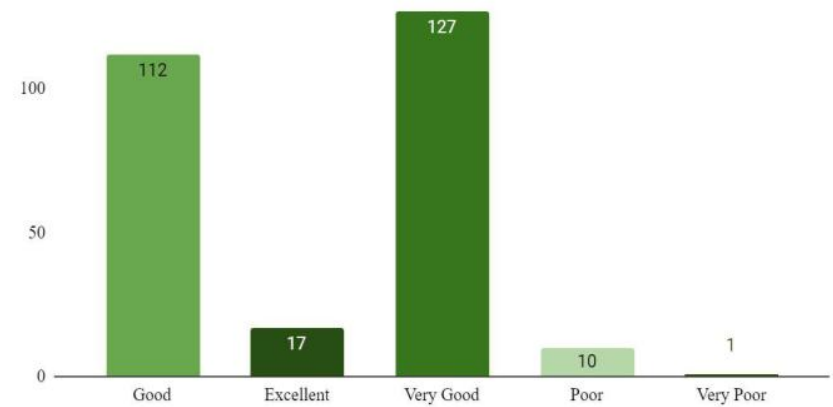

Similarly, study went further to asked respondents their own view about satisfaction with the fund utilization. The result represented in figure 4.6 shows that 121 respondents representing $45 \%$ viewed that they are satisfied with the fund utilization by the Local Government while 146 respondents representing $55 \%$ said that they do not satisfied with fund utilization by the Local Government.

Figure 4.6: Satisfaction with Fund Utilization

Satisfaction with Fund Utilization

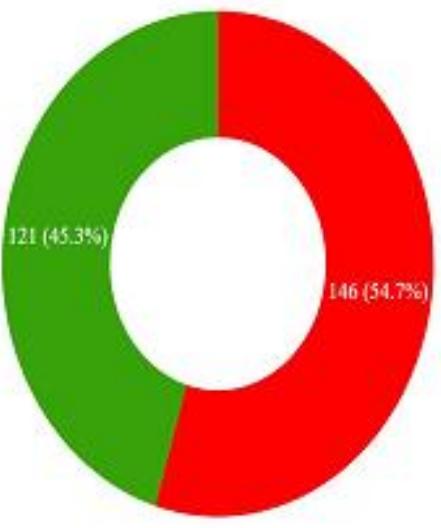

\section{Provision of Infrastructural Development}

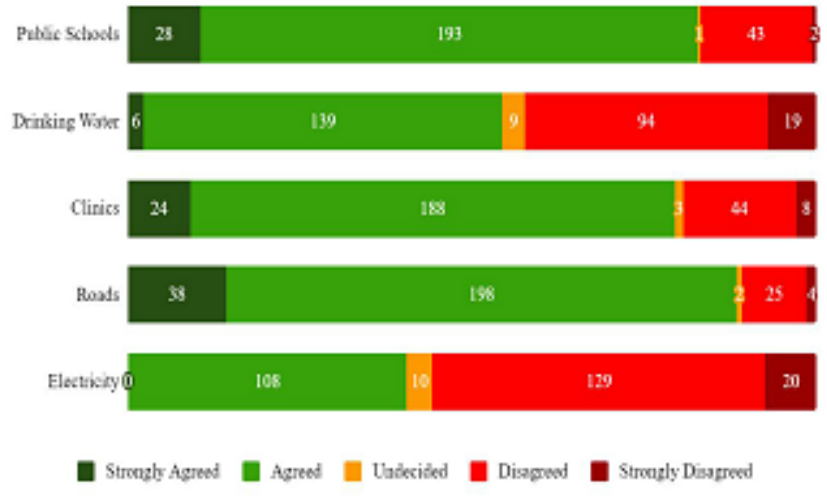

Figure 4.7: Provision of Infrastructural Development

Finally, the respondents were asked their view about the provision of infrastructural development such as; public schools, drinking water, clinics, roads, and electricity in Nassarawa Local Government. The result presented in figure 4.6 shows that out of 267 respondents, 193 representing $72 \%$ agreed that public schools were provided, while 28 respondents representing $11 \%$ were strongly agreed. However, 43 respondents representing 16\% disagreed while 2 respondents representing $1 \%$ strongly disagreed and another 1 respondent representing $0.4 \%$ remain undecided.

With respect to drinking water, respondents were asked whether Nassarawa Local Government provide adequate drinking water. Out of 267 respondents, 139 representing 52\% agreed while 6 respondents representing 2\% strongly agreed. However, 94 respondents representing 35\% disagreed while 19 respondents representing $7 \%$ strongly disagreed and another 9 respondents representing 3\% remain undecided.

With regards to clinics, the respondents were asked whether the Nassarawa Local Government provide clinics. Out of 267 respondents 188 representing $70 \%$ agreed while 24 respondents representing $9 \%$ were strongly disagreed. However, 44 respondents representing $17 \%$ disagree while 8 respondents representing 3\% strongly disagreed and another 3 respondents representing $1 \%$ remain undecided.

In terms of road infrastructure, respondents were asked whether Nassarawa Local Government provide roads. Out of 267 respondents 198 representing 74\% agreed while 38 respondents representing 14\% strongly agreed. However, 25 respondents representing $9 \%$ disagreed while respondents representing $2 \%$ strongly disagreed and another 2 respondents representing $1 \%$ remain undecided.

The respondents were also asked their views about whether the Nassarawa Local Government provides adequate power supply. Out of 267 respondents, 108 respondents representing $41 \%$ agreed. However, 129 respondents representing $48 \%$ disagreed while 20 respondents representing $8 \%$ strongly 
disagreed and another 10 respondents representing $4 \%$ remain undecided.

Therefore, in the area of infrastructural development, most of the respondents agreed that the Nassarawa Local Government provides public schools, drinking water, clinics, and roads. However, most of the respondents viewed that electricity is not adequately provided.

\section{CONCLUSION AND RECOMMENDATIONS}

The study examined the development capability of Nassarawa Local Government of Kano State. A conclusion that can be drawn from this study is that the Nassarawa Local Government has the capability to act and commit to development, deliver on development projects, adapt and selfrenew its capacity building, as well as adapt and relate with external stakeholders. However, notwithstanding, the Nassarawa Local Government faces some challenges which hinders the ability to adequately utilize the resources and government revenue generation.In line with the above findings, the paper makes the following recommendations:

i. The Nassarawa Local Government should ensure that she is effectively able to make decisions and commitments on viable policies that will improve the development capabilities of the Local Government.

ii. The Nassarawa Local Government should improve on her capability to deliver on development projects by ensuring that the local government has sufficient and capable staff; clear organizational responsibilities; adequate financial resources; and effective administrative mechanisms in place.

iii. The Nassarawa Local Government should improve on her capability to adapt and self-renew its capacity building by regularly monitoring and evaluating the progress made on its development objectives, and to encourage internal learning and reflection.

iv. The Nassarawa Local Government should improve on her capability to relate with external stakeholders by adopting the policy of Public Private Partnership as well as establishing a cordial relationship with NGOs and international organizations.

\section{REFERENCES}

[1] Ademalekun .L. (1979) The New Local System in Nigeria: Problems and Prospects for Implementation

[2] Amin, M. E. (2005). Social science research: Conception, methodology and analysis. Kampala: Makerere University Printery.

[3] Asaju, K. (2010). Local Government autonomy in Nigeria: Politics and challenges of the 1999 constitution. International Journal of Advanced Legal Studies and Governance Vol.1 No.1, April 2010

[4] Benjamin, C. (2002). The nature and accumulation of organizationalcompetences/capabilities. Revista Brasileira de Inovação Vol. 1 Número 2 Julho / Dezembro 2002

[5] Benjamin, S. A. (1998). Local Government Autonomy in Nigeria: its Implications for the Federal Structure. Ibadan,

[6] Blair, G. S. (1977). Government at the Grassroots.California, Palisades Publishers.
[7] Collins C. (1961) On Human Communication New York, New York Wiley Ejiofor, L.U. (1981) Capability Analysis of Political System, Unpublished Mimeograph, U.N.N.

[8] Doho, A. W., Ahmed, A., \& Umar, A. (2018). Local Government Autonomy In Nigeria: Struggles And Challenges. Advances in Social Sciences Research Journal, 5(5) 44-51.

[9] Federal Republic of Nigeria, the Constitution of the Federal Republic of Nigeria, 1979.

[10] Gboyega, A. (1987). Political Values and Local Government in Nigeria.Lagos, Malthouse Press Ltd.

[11] Hans, B. and Jamie, B. (2015).Improving local government performance by strengthening their 5 core capabilities.Hague, May 2015.

[12] Ingrid, R. (2003). The capability approach: An interdisciplinary introduction. Revised version 9 December 2003

[13] Johnsen, A. (1999). Performance measurement in Local Government (Norwegian School of Economics and Business Administration).

[14] Kaka, E. B. (2018).Decentralization of Local Government and rural development in Rivers State, Nigeria (Walden University).

[15] Manyi, E. E. (2007). Local Governments and rural development : A case study ofBuea in Cameroon (University of Oslo, Blindern, Norway).

[16] Myrdal G. (1955) Local Government London English University Press P.9

[17] Nigeria Union of Local Government Employees (2003). A Position Paper Presented at CONFAB, Abuja(Unpublished).

[18] Nkong, E.E (1977) Evaluating Development The Case of Western Niger. I Hesha, Wesha Press and Sons Nig. Ltd Ilesha.

[19] Oduro-Ofori, E. (2011). The role of Local Government in local economic development promotion at the district level in Ghana: A Study of the Ejisu-Juaben Municipal Assembly (Technical University ofDortmund, Germany)

[20] Okoli E. (1998) National Conference on The New Local Government System in Nigeria. Pirages, D.(1976) Managing Conflict, Nelson Publisher Enugu.

[21] Ola, R. F. (1984). Local Administration in Nigeria.London, Kegan Paul International.

[22] Oni, S. and Joshua, S. (2014). The legislature and representative democracy in the Local Government system of Nigeria's fourth republic.Journal of Sustainable Development in Africa (Volume 16, No.2, 2014)

[23] Otoghile, A. and Edigin, L. U. (2011).Local government administration and development: A survey of Oredo Local Government Area of Edo State, Nigeria. An International Multi- Disciplinary Journal, Ethiopia; Vol. 5 (3), Serial No. 20, May 2011

[24] Rodney W. (1972) How Europe Underdeveloped Africa. London, Bog L.L Overture Publication, P 10

[25] SalahudeenHajarat (2018) Analysis of Accessibility and Distribution of Domestic Water Supply in Nassarawa Local Government Area of Kano State, Nigeria. ATBU, Journal of Science, Technology \& Education (JOSTE); Vol. 6(2)

[26] Sokar, A.P. (1978). Bringing the government closer to the people, myth or reality: The military and local government in TW Land, 1966-1979.Unpublished M Sc thesis.

[27] Todaro, M.P. (1981). Economic development in the third world. Second Edition, Longman, 1981

[28] Young O. (1968) System of Political Science New Jersey Prensi Hall Inc, P.29.The Ash Ridge Conference on Social Development. (1954) Colonial Office Miscellaneous No. 523. 